\title{
Gambaran Epidemiologi Penyakit Tuberkolusis Paru (TB PARU) di Kabupaten Indramayu
}

\author{
Setyo Dwi Widyastuti ${ }^{1}$, Riyanto ${ }^{2}$, Muhamad Fauzi ${ }^{3)}$ \\ ${ }^{1,3)}$ Dosen Prodi Sarjana Kesehatan Masyarakat, \\ ${ }^{2}$ Dosen Prodi Sarjana Keperawatan, Sekolah Tinggi Ilmu Kesehatan (STIKes) Indramayu \\ e-mail:niamulwafa70@gmail.com
}

\begin{abstract}
Pulmonary TB disease in Indramayu District is still a public health problem. With descriptive epidemiology can be utilized further to know the factors that influence the bigh frequency of pulmonary TB disease in Indramayu District. The purpose of this research is to know the epidemiological picture of pulmonary TB disease in Indramayu Regency in 2016. Quantitative descriptive research method. Sampling by cluster sampling technique. Data were analyzed using descriptive statistic analysis technique. Based on the result of research, it is known that the prevalence of pulmonary tuberculosis disease in Puskesmas Jatibarang, Puskesmas Kertasemaya and Puskesmas Losarang is 141 people, with the following distribution: according to the variables, $85.5 \%$ are between $15-64$ years old, $66.1 \%$ male, $32.3 \%$ unemployed, $29 \%$ not yet I no school, 61.3\% socioeconomic low, 67.7\% marital status married, 37.7\% large family more than 4 people, $51.6 \%$ other than pulmonary TB disease, and $59.7 \%$ have sufficient knowledge about pulmonary TB disease. Place variables, $40.3 \%$ in Puskesmas Kertasemaya, and 90.3\% lived in the village. While based on the time variable, 33.9\% of pulmonary tuberculosis patients were diagnosed in the first trimester with $62.3 \%$ treatment duration over 6 months. Suggestions for puskesmas to further improve health promotion activities, and for the community to take an active role in preventing the transmission of pulmonary tuberculosis.
\end{abstract}

Keywords: Descriptive Epidemiology, Pulmonary TB

\begin{abstract}
ABSTRAK
Penyakit TB Paru di Kabupaten Indramayu masih menjadi masalah kesehatan masyarakat. Dengan epidemiologi deskriptif dapat dimanfaatkan lebih lanjut untuk mengetahui factorfaktor yang mempengaruhi tingginya frekuensi penyakit TB paru di Kabupaten Indramayu. Tujuan penelitian ini adalah ingin mengetahui gambaran epidemiologi penyakit TB paru di Kabupaten Indramayu tahun 2016. Metode penelitian deskriptif kuantitatif. Pengambilan sampel dengan teknik cluster sampling. Data dianalisis dengan menggunakan teknik analisis statistik deskriptif. Berdasarkan hasil penelitian diketahui bahwa prevalensi penyakit TB paru di Puskesmas Jatibarang, Puskesmas Kertasemaya dan Puskesmas Losarang sebanyak 141 orang, dengan distribusi sebagai berikut: menurut variabel orang, 85,5\% berumur antara 15 64 tahun, 66,1\% berjenis kelamin laki-laki, 32,3\% tidak bekerja, 29\% belum/tidak sekolah, $61,3 \%$ sosial ekonominya rendah, $67,7 \%$ status perkawinannya kawin, 37,7\% besar keluarga lebih dari 4 orang, 51,6\% tidak menderita penyakit lainnya selain penyakit TB paru, dan $59,7 \%$ mempunyai pengetahuan yang cukup tentang penyakit TB paru. Variabel tempat,
\end{abstract}


40,3\% di Puskesmas Kertasemaya, dan 90,3\% tinggal di desa. Sedangkan berdasarkan variabel waktu, 33,9\% penderita TB paru didiagnosa pada trimester I dengan lama pengobatan $62,3 \%$ lebih dari 6 bulan. Saran bagi puskesmas agar lebih meningkatkan lagi kegiatan promosi kesehatan, dan untuk masyarakat agar berperan aktif dalam melakukan upaya pencegahan terhadap penularan penyakit TB paru.

Kata Kunci : Epidemiologi Deskriptif, TB Paru

\section{PENDAHULUAN}

TB paru atau dikenal juga dengan istilah tuberkolusis paru (TB paru) merupakan masalah global, dimana World Health Organization (WHO) memperkirakan setiap tahun masih terdapat sekitar sembilan juta penderita TB paru dengan 3 juta kematian akibat TB diseluruh dunia. Diperkirakan 95\% kasus TB dan 98\% kematian akibat TB di dunia, terjadi di Negara-negara berkembang(Kemenkes, 2010)

Negara Indonesia sekarang menurut WHO berada pada ranking keempat Negara dengan beban TB tertinggi di dunia setelah India, Cina, dan Afrika Selatan. Dari semua kasus TB pada tahun 2010, 13\% diantarannya disertai dengan infeksi HIV (WHO, 2011). Jumlah kematian akibat TB diperkirakan 61.000 kematian per tahunnya (Kemenkes, 2010)

Pada tahun 2012, prevalensi penyakit TB paru di Propinsi Jawa Barat sebanyak 138/100.000 penduduk dengan distribusi yang berjenis kelamin laki-laki
$151 / 100.000$ penduduk dan yang berjenis kelamin perempuan 125/100.000 penduduk. Frekuensi penderita baru (insidensi) 60.765 jiwa dan kasus lama 62.225 jiwa. Angka kematian karena penyakit TB paru pada kasus baru yaitu sebanyak 122/100.000 penduduk dan kasus lama sebanyak 134/100.000 penduduk. (Profil Kesehatan Propinsi Jawa Barat, 2012).

Penyakit TB paru di Kabupaten Indramayu berdasarkan data dalam profil kesehatan Propinsi Jawa Barat, pada tahun 2012, prevalensi penyakit TB paru 192/100.000 penduduk, dengan distribusi 112/100.000 penduduk laki-laki dan 80/100.000 penduduk perempuan, sedangkan insidensi penyakit TB paru 1.602 penduduk, dengan distribusi 960 penduduk laki-laki dan 642 penduduk perempuan. (Profil Kesehatan Propinsi Jawa Barat, 2012)

Epidemiologi deskriptif adalah epidemiologi yang hanya mempelajari tentang frekuensi dan penyebaran suatu 
masalah kesehatan saja. Banyak manfaat yang dapat diperoleh dengan mempelajari epidemiologi deskriptif, antara lain dapat mengetahui frekuensi dan distribusi masalah kesehatan atau penyakit menurut keadaan tertentu. Keadaan tertentu yang dimaksud disini adalah menurut variable orang, variable tempat dan variable waktu. Dengan mengetahui varibel orang, variable tempat dan variable waktu dapat digunakan sebagai dasar untuk mengetahui factor penyebab terjadinya suatu masalah kesehatan pada suatu tempat. (Azwar, 2001)

Penyakit TB paru selama ini masih menjadi masalah kesehatan masyarakat, termasuk di Kabupaten Indramayu, yang ditandai dengan masih tingginya prevalensi dan insidensi penyakit tersebut. Dalam pencatatan dan pelaporan penyakit TB paru variable yang dicatat yang termasuk dalam epidemiologi deskriptif baru meliputi : umur, jenis kelamin dan pekerjaan, alamat, waktu diagnosa dan waktu sembuh, serta trimester. Padahal dengan epidemiologi deskriptif dapat dimanfaatkan lebih lanjut untuk mengetahui factor-faktor yang mempengaruhi tingginya frekuensi penyakit TB paru di Kabupaten Indramayu.
Tujuan dari penelitian ini adalah untuk mengetahui gambaran epidemiologi penyakit TB paru di Kabupaten Indramayu.

\section{METODE PENELITIAN}

Rancangan penelitian ini menggunakan metode deskriptif kuantitatif.

Etik dalam penelitian ini, antara lain: menjamin kerahasiaan responden, menjamin keamanan responden, bertindak adil, dan mendapatkan persetujuan dari responden.

Populasinya adalah penderita TB paru di Kabupaten Indramayu, dengan penentuan sampel secara cluster sampling. Penderita TB Paru yang terpilih adalah penderita TB Paru yang berada di wilayah kerja Puskemas Kertasemaya (mewakili wilayah Indramayu bagian Timur), Puskesmas Jatibarang mewakili wilayah Indramayu bagian Tengah), dan Puskesmas Losarang mewakili wilayah Indramayu bagian Barat atau Pantura), dengan jumlah sampel sebanyak 141 penderita TB paru, dan yang bisa diteliti sebanyak 62 penderita TB Paru. (Kriteria inklusi: penderita TB Paru yang di diagnosa tahun 2016, berumur $\geq$ 15 tahun dan kriteria eksklusi: tidak berada 
di rumah saat dilakukan penelitian, dan bisa berbicara (tidak bisu)

Instrumen dalam penelitian ini menggunakan kuesioner. Analisis data dengan menggunakan analisis univariat. Data disajikan dalam bentuk tabel dan grafik serta diinterpretasikan. Variabelvariabel yang dianalisis, antara lain : variabel orang, variabel tempat, dan variabel waktu. Tampilan datanya berupa frekuensi dan persentase.

\section{HASIL PENELITIAN}

\section{Prevalensi Penyakit TB paru}

Berdasarkan data sekunder yang diperoleh dari Puskesmas Jatibarang, Puskesmas Kertasemaya, dan Puskesmas Jatibarang, diketahui prevalensi penyakit TB paru pada tahun 2016 adalah sebanyak 141 penderita penyakit TB paru.

Berdasarkan Tabel 1, diketahui bahwa, penderita TB paru $85,5 \%$ berumur antara 15-64 tahun, dan secara rata-rata umur penderita penyakit TB paru adalah 44 tahun dengan umur termuda 16 tahun dan umur tertua 77 tahun, $66,1 \%$ berjenis kelamin laki-laki, 32,3\% belum/tidak bekerja, 29,0\% belum/tidak sekolah, $29,0 \%$ berpendidikan SMA/sederajat, $61,3 \%$ berpendapatan kurang dari
Rp 1.650.000,- atau status sosial ekonominya rendah, $67,7 \%$ status perkawinannya kawin, $37,1 \%$ besar keluarga atau banyaknya orang yang tinggal satu rumah lebih dari 4 orang, $32,3 \%$ penyakit lain yang diderita oleh penderita TB Paru menderita adalah penyakit lain-lainnya, dan 59,7\% pengetahuan penderita TB paru tentang penyakit TB paru masuk dalam kategori cukup baik.

Berdasarkan Variabel Tempat diketahui bahwa, dari 3 (tiga) Puskesmas wilayah penelitian, 40,3\% penderita TB paru pada tahun 2016 ditemukan di wilayah kerja Puskesmas Kertasemaya dan 90,3\% tinggal di wilayah dalam kategori desa.

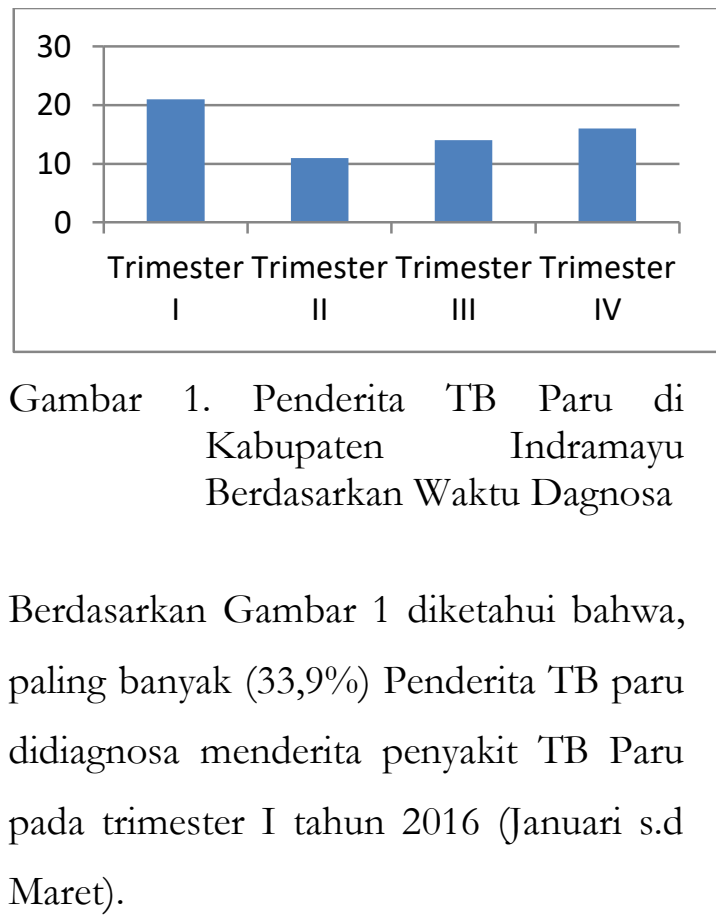


Tabel 1. Distribusi Frekuensi Penderita TB Paru Berdasarkan Variabel Orang di Kabupaten Indramayu

\begin{tabular}{|c|c|c|}
\hline Variabel Orang & $\mathbf{F}$ & $\%$ \\
\hline \multicolumn{3}{|l|}{ Umur (Tahun) } \\
\hline $15-64$ & 53 & 85,5 \\
\hline$\geq 65$ & 9 & 14,5 \\
\hline \multicolumn{3}{|l|}{ Jenis Kelamin } \\
\hline Laki-laki & 41 & 66,1 \\
\hline Perempuan & 21 & 33,9 \\
\hline \multicolumn{3}{|l|}{ Pekerjaan } \\
\hline Belum/tidak bekerja & 20 & 32,3 \\
\hline Petani & 9 & 14,5 \\
\hline Swasta & 3 & 4,8 \\
\hline Wiraswasta & 19 & 30,6 \\
\hline PNS/TNI/Polri/BU & 1 & 1,6 \\
\hline $\mathrm{MN}$ & 10 & 16,1 \\
\hline Lainnya & & \\
\hline \multicolumn{3}{|l|}{ Pendidikan } \\
\hline Belum/Tidak Sekolah & 18 & 29,0 \\
\hline $\mathrm{SD} /$ Sederajat & 12 & 19,4 \\
\hline SMP/Sederajat & 12 & 19,4 \\
\hline SMA/Sederajat & 18 & 29,0 \\
\hline Perguruan Tinggi & 2 & 3,2 \\
\hline \multicolumn{3}{|l|}{ Sosial Ekonomi } \\
\hline$<\operatorname{Rp~1.650.000,-~}$ & 38 & 61,3 \\
\hline$=\operatorname{Rp} 1.650 .000,-$ & 10 & 16,1 \\
\hline >Rp 1.650.000,- & 14 & 22,6 \\
\hline \multicolumn{3}{|l|}{ Status Perkawinan } \\
\hline Kawin & 42 & 67,7 \\
\hline Duda/Janda & 11 & 17,7 \\
\hline Tidak/Belum Kawin & 9 & 14,5 \\
\hline \multicolumn{3}{|l|}{ Besar Keluarga } \\
\hline$<4$ orang & 21 & 33,9 \\
\hline$=4$ orang & 18 & 29,0 \\
\hline$>4$ orang & 23 & 37,1 \\
\hline \multicolumn{3}{|l|}{ Penyakit Lain yang } \\
\hline Diderita & 5 & 8,1 \\
\hline ISPA & 2 & 3,2 \\
\hline Diare & 1 & 1,6 \\
\hline Jantung & 1 & 1,6 \\
\hline Typhoid & 1 & 1,6 \\
\hline Hipertensi & 32 & 51,6 \\
\hline Tidak Sakit & 10 & 32,3 \\
\hline Lainnya & & \\
\hline \multicolumn{3}{|l|}{ Pengetahuan Tentang } \\
\hline Penyakit TB Paru & & \\
\hline Kurang & 15 & 24,2 \\
\hline Cukup & 37 & 59,7 \\
\hline Baik & 10 & 16,1 \\
\hline
\end{tabular}

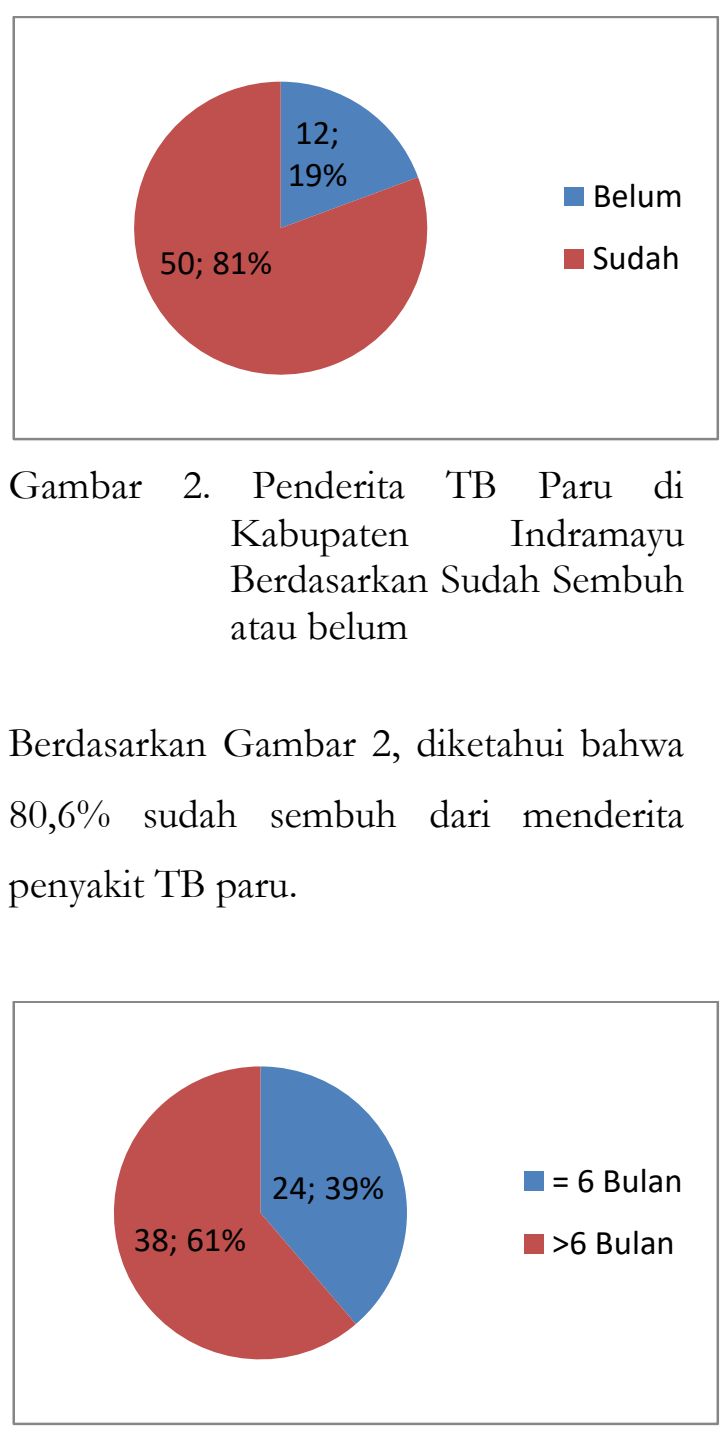

$$
\begin{array}{rrr}
\text { Gambar 3. } & \text { Penderita } & \text { TB Paru di } \\
& \text { Kabupaten } & \text { Indramayu } \\
& \text { Berdasarkan } & \text { Lama } \\
& \text { Pengobatan } &
\end{array}
$$

Berdasarkan Gambar 3 diketahui bahwa $62,3 \%$ lama pengobatannya lebih dari 6 bulan, yang kalau dihitung secara ratarata, lama pengobatan penyakit TB paru adalah 9 bulan, dan waktu terlama adalah 22 bulan. 


\section{PEMBAHASAN}

Prevalensi adalah gambaran frekuensi penderita lama dan penderita baru suatu penyakit tertentu pada wilayah tertentu dan pada waktu tertentu. (Azwar, 2001). Prevalensi adalah Kejadian penyakit pada satu saat atau satu periode waktu, baik yang baru saja memasuki fase klinik maupun yang telah beberapa waktu lamanya berkembang sepanjang fase klinik (Murti, 1997). Ukuran prevalensi penyakit dapat dimanfaatkan untuk menilai kualitas dan kuantitas pelayanan kesehatan. (Murti, 1997)

Bila dibandingkan dengan tahun-tahun sebelumnya, yaitu pada tahun 2013 dan tahun 2015, terdapat fluktuasi prevalensi penyakit TB Paru di 3 puskesmas tersebut. Banyak faktor yang mempengaruhi prevalensi suatu penyakit. Faktor-faktor yang meningkatkan prevalensi penyakit, antara lain: durasi penyakit yang lama, pemanjangan usia penderita tanpa pengobatan, peningkatan kasus-kasus baru (peningkatan insidensi), kasus-kasus migrasi ke dalam populasi, migrasi keluar dari orang-orang yang sehat, migrasi ke dalam orang-orang yang rentan, dan peningkatan sarana diagnostik. Sedangkan faktor-faktor yang menurunkan prevalensi penyakit adalah durasi penyakit yang lebih pendek, meningkatnya tingkat fasilitas kasus akibat dari penyakit, menurunnya kasus-kasus baru (menurunnya insidensi), migrasi ke dalam dari orang-orang yang sehat, migrasi keluar dari kasus-kasus, dan meningkatnya tingkat kesembuhan untuk kasus-kasus penyakit. (R. Beaglehole, at all, 1997)

\section{Variabel Orang}

Variabel orang adalah semua ciri atau karakteristik yang terdapat pada diri manusia yang dapat mempengaruhi terjadi tidaknya suatu penyakit. (Azwar, 2001).

Berdasarkan hasil penelitian diketahui bahwa 85,5\% penderita TB Paru di Kabupaten Indramayu berumur antara 15-64 tahun, dengan rata-rata penderita TB paru berumur 44 tahun, umur termuda berumur 16 tahun dan tertua berumur 77 tahun.Dibandingkan dengan data penderita TB paru secara nasional, umur penderita TB paru di Kabupaten Indramayu sama dengan umur penderita TB paru secara nasional, yaitu sebagian besar berada pada umur antara 15-64 Tahun. (Kemenkes, 2015) 
Hasil penelitian ini sama dengan hasil penelitian yang dilakukan oleh Laily, dkk (2015) tentang Karakteristik Pasien tuberkolusis paru di Puskesmas Tuminting Manado, bahwa penderita TB paru berdasar umur 96,6\% berumur antara 15-65 tahun.Hasil penelitian ini sejalan pula dengan hasil penelitian yang dilakukan oleh Panjaitan (2012) tentang karakteristik penderita tuberkolusis paru dewasa rawat inap di Rumah Sakit DR. Soedarso Pontianak Periode SeptemberNovember 2010 diketahui 77,8\% berumur produktif, dengan rata-rata umur 44,2 tahun.

Umur termasuk variabel orang yang penting untuk diteliti dalam mempelajari kejadian suatu penyakit, karena ada kaitannya dengan daya tahan tubuh,berkaitan dengan ancaman terhadap kesehatan, ada kaitannya dengan kebiasaan hidup(Azwar, 2001).Penyakit TB paru merupakan penyakit khronis yang dapat menyerang pada semua kelompok umur.

Berdasarkan hasil penelitian diketahui bahwa $66,1 \%$ penderita TB paru berjenis kelamin laki-laki dan 33,9\% penderita TB paru berjenis kelamin perempuan.Hasil penelitian ini sama dengan data nasional penderita TB paru pada tahun 2015, bahwa menurut jenis kelamin, jumlah penderita laki-laki lebih tinggi bila dibandingkan perempuan, yaitu 1,5 kali dibandingkan pada perempuan. Demikian juga dilihat pada masing-masing propinsi di seluruh Indonesia penderita TB paru lebih banyak terjadi pada laki-laki dibandingkan perempuan. (Kemenkes, 2015). Hasil penelitian ini sejalan dengan penelitian yang dilakukan oleh Laily, dkk (2015) tentang karakteritik pasien tuberkolusis paru di Puskesmas Tumiting Manado, bahwa 55,1\% penderita TB paru berjenis kelamin laki-laki. Hasil penelitian ini sejalan pula dengan hasil penelitian yang dilakukan oleh Fitria, dkk (2017) tentang karakteristik Penderita tuberkolusis paru di Puskesmas Rujukan Mikroskopis Kabupaten Aceh Besar, bahwa $71,43 \%$ penderita TB paru berjenis kelamin laki-laki.

Jenis kelamin juga mempengaruhi penyebaran suatu masalah kesehatan. Ada masalah kesehatan yang lebih banyak ditemukan pada kelompok wanita saja, dan adapula masalah kesehatan yang lebih banyak ditemukan pada kelompok pria saja. Adanya perbedaan penyebaran yang seperti ini dapat disebabkan oleh bebrapa hal, yakni karena terdapatnya perbedaan 
anatomi dan fisiologi antara wanita dengan pria, perbedaan kebiasaan hidup, tingkat kesadaran berobat, kemampuan atau kriteria diagnostik beberapa penyakit, macam pekerjaan (Azwar, 2001).

Tinggi proporsi penderita TB paru pada laki-laki dibanding perempuan, salah satunya disebabkan oleh karena terdapatnya perbedaan kebiasaan hidup antara laki-laki dan perempuan..

Berdasarkan hasil penelitian diketahui bahwa 32,3\% penderita TB paru belum/tidak bekerja dan 30,6\% penderita TB paru bekerja sebagai wiraswasta.Hasil penelitian ini sejalan dengan penelitian yang dilakukan oleh Prihantana (2016) tentang hubungan antara pengetahuan dengan tingkat kepatuhan pengobatan pada pasien tuberkulosis di RSUD dr. Soehadi Prijonegoro Sragen, bahwa 27,5\% penderita TB paru tidak bekerja atau sebagai ibu rumah tangga, dan persentase terbesar kedua adalah $22,5 \%$ penderita TB paru bekerja disektor swasta atau wiraswasta.

Hubungan antara pekerjaan dengan masalah kesehatan, pada dasarnya hubungan yang terjadi disebabkan oleh adanya risiko pekerjaan, seleksi alamiah dalam memilih pekerjaan, perbedaan status sosial ekonomi(Azwar, 2001). Perbedaan macam pekerjaan yang dimiliki seseorang, menyebabkan terdapatnya pula perbedaan status sosial ekonomi yang dimiliki. Adanya perbedaan yang seperti ini menyebabkan terdapatnya perbedaan penyakit yang dideritanya. (Azwar, 2001).

Berdasarkan hasil penelitian diketahui bahwa 29\% penderita TB Paru termasuk kedalam kategori Belum/Tidak Sekolah dan sebanyak 29\% termasuk ke dalam kategori berpendidikan SMA/Sederajat. Hasil penelitian ini sejalan dengan penelitian yang dilakukan oleh Rukmini dan Chatarina UW (2010) bahwa sebagian besar penderita TB paru tidak sekolah/tidak tamat SD/tamat SD.Pengetahuan penderita tentang TB Paru di pengaruhi oleh latar belakang pendidikan, pengetahuan yang baik tentang TB Paru dapat memberikan pengaruh yang positif terhadap proses penyembuhan, hal ini sesuai dalam Kemenkes (2015) bahwa tingkat pendidikan yang relatif rendah pada penderita TB Paru menyebabkan keterbatasan informasi tentang gejala dan pengobatan. Pendidikan yang rendah juga tidak menjamin terhadap kurangnya kesadaran masyarakat terhadap kesehatan diri dalam hal ini berupa pencegahan 
terhadap penyakit khususnya penyakit TB Paru.

Tingkat pendidikan pasien dapat meningkatkan kepatuhan, sepanjang bahwa pendidikan tersebut merupakan pendidikan yang aktif yang diperoleh secara mandiri, lewat tahapan-tahapan tertentu. Seseorang atau pasien yang dibekali informasi akan memiliki kemungkinan lebih besar untuk mematuhi rencana pengobatan medis dan mendapatkan cara untuk mengatasi penyakit, menjadi lebih mampu mengatasi gejala penyakit, dan kemungkinannya mengalami komplikasi lebih kecil. Dalam hal ini pendidikan kesehatan sangat dibutuhkan oleh pasien dan keluarga (Notoatmodjo, 2007).

Berdasarkan hasil penelitian diketahui bahwa $61,3 \%$ pendapatan ekonomi penderita TB Paru berada pada kisaran kurang dari 1. 650.000,-. Sosial ekonomi sangat mempengaruhi sekali terhadap derajat kesehatan masyarakat. Status sosial ekonomi penderita TB Paru sebagian besar tidak bekerja dan sebagian lagi sebagai wiraswasta hal ini menunjukkan bahwa pendapatan ekonomi keluarga sebagian besar masih di bawah UMR.
Pendapatan keluarga dapat mempengaruhi perilaku pengobatan penyakit TB dikarenakan penghasilan keluarga lebih difokuskan pada kebutuhan sehari-hari (Erawatyningsih, 2009). Disamping itu juga pendapatan keluarga mempengaruhi pola konsumsi makanan maupun dalam upaya pemeliharaan kesehatan baik kesehatan individu, keluarga maupun kesehatan pemukiman. Keluarga yang mempunyai pendapatan di bawah UMR seringkali mengkonsumsi makanan dengan kadar gizi tidak sesuai dengan kebutuhan gizi keluarga sehingga akan memudahkan terkena penyakit infeksi diantaranya penyakit TB Paru.

Berdasarkan hasil penelitian diketahui bahwa sebanyak 67,7\% Penderita TB Paru berstatus kawin. Hal ini sesuai dengan hasil penelitian Sihombing (2012) yang didapatkan hasil bahwa sebagian besar yaitu $80 \%$ penderita TB bersetatus kawin. Ada beberapa faktor yang dapat menyebabkan penyakit TB Paru jika dilihat dari status perkawinan diantaranya, penghasilan keluarga yang belum dapat mencukupi sehingga dalam pola hidup berkeluarga belum menerapkan perilaku hidup bersih dan sehat sehingga derajat kesehatan gizi keluarga kurang, alokasi pendapatan lebih banyak jika sudah 
mempunyai anak. Di samping itu juga dalam upaya penyembuhan penyakit TB Paru seharusnya akan lebih baik lagi terutama dalam pengawasan minum obat artinya suami/istri maupun anak dapat dijadikan sebagai Pengawas Minum Obat (PMO) agar penderita tidak putus di tengah jalan dalam minum obat sehingga dapat mengakibatkan pengulangan kembali dari awal dengan kadar obat yang lebih tinggi dari obat yang pertama.

Berdasarkan hasil penelitian diketahui bahwa sebanyak $37,1 \%$ mempunyai jumlah keluarga lebih dari 4 orang. Semakin banyak anggota keluarga maka semakin besar pula tanggungan keluarga dalam mencukupi kebutuhan hidup keluarga.Anggota keluarga yang banyak tanpa diimbangi dengan pendapatan yang mencukupi akan sangat membahayakan terhadap status gizi, tingkat pendidikan dan pekerjaan anggota keluarga sehingga akan beresiko terhadap kelangsungan hidup keluarga tersebut. Anggota keluarga yang padat juga dapat mempengaruhi kejadian TB Paru, hal ini sesuai dengan penelitian Simbolon (2007) yang didapatkan hasil interaksi penghuni rumah yang padat dapat meningkatkan risiko TB Paru.
Pendapatan yang masih dibawah UMR dengan mempunyai anggota keluarga lebih dari 4 orang maka kebutuhan pangan keluarga akan meningkat sehingga pihak keluarga akan lebih menghemat pengeluaran. Pola makan seadanya tanpa menghiraukan kandungan gizi maka keluarga tersebut akan mudah terjangkit penyakit. Upaya yang mungkin dilakukan dengan melakukan sosialisasi kepada kepala keluarga untuk dapat meningkatkan pendapatannya dengan berwirausaha serta membatasi jumlah anak sehingga akan menjadikan keluarga yang sehat dan sejahtera.

Berdasarkan hasil penelitian diketahui bahwa lebih dari setengahnya responden masuk ke dalam kategori tidak sakit akan tetapi meskipun demikian ada beberapa penyakit yang diderita oleh penderita TB Paru di antaranya penyakit ISPA, Diare, Jantung, Typoid, Hipertensi dan penyakit lainnya yang merupakan ancaman kesehatan penderita TB Paru.Tingginya angka kesakitan menandakan bahwa pola perilaku hidup bersih dan sehat di masyarakat tersebut belum dijadikan sebagai pedoman hidup bermasyarakat sehingga perlu ditingkatkan pengetahuan masyarakat terhadap bahaya penyakit serta cara pencegahannya dengan melakukan 
sosialisasi, penyuluhan dan pendidikan perilaku oleh petugas kesehatan. Masalah kesehatan bukan hanya masalah individu akan tetapi tanggungjawab kita bersama yang harus kita temukan jalan keluar dan cara penyelesaian masalahnya sehingga masyarakat terbebas dari berbagai jenis penyakit.

Berdasarkan hasil penelitian diketahui bahwa tingkat pengetahuan penderita TB Paru 59,7\% termasuk ke dalam kategori cukup sehingga perlu peningkatan lagi sehingga pengetahuan penderita tentang TB Paru akan lebih baik lagi.

Penunjang keberhasilan pengobatan TB Paru adalah dengan mengetahui seberapa jauh pengetahuan penderita tentang TB Paru yang meliputi gejala, penularan, pencegahan dan pengobatan TB Paru. Pengetahuan yang rendah akan mengurangi perilaku pengobatan yang baik pada masyarakat, hal ini sesuai dengan penelitian Erawatyningsih (2009) bahwa tingkat pengetahuan penderita yang rendah akan berisiko lebih dari dua kali terjadi kegagalan pengobatan dibandingkan dengan penderita yang memiliki pengetahuan tinggi.
Pengetahuan masyarakat tentang TB Paru masih dikatakan kurang sehingga perlu ditingkatkan lagi proses sosialisasi yang dilakukan oleh pemegang program TB karena pengetahuan masyarakat atau penderita akan gejala dan cara penularannya sangat penting untuk di pahami. Dalam penelitian ini penderita memiliki pengetahuan yang cukup akan tetapi penderita memahami sedikit informasi yang mereka dapat dengan baik. Sehingga saat penderita memiliki pemahaman yang baik maka diharapkan aplikasi juga baik.

Berdasarkan hasil penelitian diketahui bahwa, dari 3 (tiga) Puskesmas wilayah penelitian, 40,3\% penderita TB paru pada tahun 2016 ditemukan di wilayah kerja Puskesmas Kertasemaya.

Keadaan pelayanan kesehatan yang ditemukan di suatu tempat juga mempengaruhi penyebaran penyakit di tempat tersebut. Masalah pelayanan kesehatan ini tidak hanya yang menyangkut jumlah dan cakupannya saja, tetapi juga mutu pelayanan kesehatan yang diselenggarakan.

$\begin{array}{llr}\text { Karakteristik } & \text { wilayah } & \text { puskesmas } \\ \text { Kertasemaya } & \text { merupakan } & \text { daerah }\end{array}$ 
perbatasan antara Wilayah Indramayu dengan Wilayah Kabupaten Cirebon. Hal ini bisa berakibat kontrol atau pengobatan para penderita TB Paru tidak terpantau karena bisa saja penderita yang berada di wilayah perbatasan bisa berobat di dua tempat yang berbeda.Berdasarkan hasil penelitian diketahui bahwa, 90,3\% penderita TB Paru tinggal di wilayah desa. Penyebaran masalah kesehatan (Azwar, 2001) ditentukan dari 1).Keadaan geografis. Misalnya letak wilayah, struktur tanah, curah hujan, sinar matahari, angin, kelembapan udara, suhu udara dan lain sebagainya.Pada umumnya wilayah desa jauh dari sarana pelayanan kesehatan, sehingga akses penduduk akan pelayanan kesehatan dan juga informasi-informasi tentang kesehatan terbatas, 2). Keadaan penduduk. Perbedaan keadaan penduduk juga menentukan perbedaan penyebab penyakit menurut tempat.Keadaan penduduk yang dapat mempengaruhi masalah kesehatan antara lain: umur, jenis kelamin, status perkawinan, sosial ekonomi, pekerjaan, besar keluarga, pendidikan, penyakit lain yang diderita, dan pengetahuan. Semua ciri tentang keadaan penduduk penderita TB paru terdapat dalam variabel orang.

\section{Variabel Waktu}

a) Berdasarkan hasil penelitian diketahui bahwa, 33,9\% responden didiagnosa menderita penyakit TB Paru pada trimester I tahun 2016 (Januari s.d Maret).Penegakan diagnosis penyakit TB dilakukan dengan pemeriksaan dahak. Pemeriksaan dahak berfungsi untuk menegakkan diagnosis, menilai keberhasilan pengobatan dan menentukan potensi penularan. Pemeriksaan dahak dilakukan dengan mengumpulkan spesimen dahak yang dikumpulkan dalam dua hari kunjungan yang berurutan berupa Sewaktu-Pagi-Sewaktu (SPS). Bila dari dua kali pemeriksaan didapatkan hasil BTA positif, maka pasien tersebut dinyatakan positif mengidap tuberkolusis paru. 1). S (Sewaktu) : dahak dikumpulkan pada saat suspek TB datang berkunjung pertama kali. Pada saat pulang, suspek membawa sebuah pot dahak untuk mengumpulkan dahak pagi pada hari kedua, 2).P (Pagi) : dahak dikumpulkan di rumah pada pagi hari kedua, segera setelah bangun tidur, pot dibawa dan diserahkan sendiri kepada petugas di unit pelayanan kesehatan, 3).S (Sewaktu) : dahak dikumpulkan di unit pelayanan kesehatan pada hari kedua, saat menyerahkan dahak pagi.

(Widoyono, 2011) 


\section{b) Lama pengobatan}

Berdasarkan hasil penelitian diketahui bahwa, 62,3\% lama pengobatannya lebih dari 6 bulan, yang kalau dihitung secara rata-rata, lama pengobatan penyakit TB paru adalah 9 bulan, dan waktu terlama adalah 22 bulan. Hasil penelitian ini sejalan dengan teori tentang penyakit TB paru bahwa pengobatan TB paru minimal dilakukan selama 6 bulan. (Kemenkes, 2010). PRINSIP pengobatan penyakit TB Paru, antara lain 1).Tahap Intensif. Pada tahap intensif (awal) penderita mendapat obat setiap hari dan perlu diawasi secara langsung untuk mencegah terjadinya kekebalan obat.Bila pengobatan tahap intensif tersebut diberikan secara tepat, biasanya penderita menular menjadi tidak menular dalam kurun waktu 2 minggu. Sebagian besar penderita TB BTA positif menjadi BTA negatif (konversi) dalam 2 bulan, 2).Tahap Lanjutan. Pada tahap lanjutan penderita mendapat jenis obat lebih sedikit, namun dalam jangka waktu yang lebih lama. Tahap lanjutan penting untuk membunuh kuman persister (dormant) sehingga mencegah terjadinya kekambuhan (Kemenkes, 2010)

\section{KESIMPULAN}

Prevalensi Penyakit TB Paru di Kabupaten Indramayu, pada tahun 2016 masih tinggi.
Gambaran epidemiologi penyakit TB paru berdasarkan variable tempat diketahui bahwa, penderita TB paru pada tahun 2016 ditemukan di wilayah kerja Puskesmas Kertasemaya dan tinggal di wilayah dalam kategori desa.

Gambaran epidemiologi penyakit TB paru berdasarkan variable waktu diketahui bahwa, penderita TB paru didiagnosa menderita penyakit TB Paru pada trimester I tahun 2016 (Januari s.d Maret), sudah sembuh dari menderita penyakit TB paru, dan lama pengobatannya lebih dari 6 bulan, yang kalau dihitung secara ratarata, lama pengobatan penyakit TB paru adalah 9 bulan, dan waktu terlama adalah 22 bulan.

Direkomendasikan Puskesmas sebagai ujung tombak pelayanan kesehatan kepada masyarakat agar lebih meningkatkan lagi kegiatan promosi kesehatan, khususnya tentang penyakit TB paru. Untuk masyarakat agar berperan aktif dalam melakukan upaya pencegahan terhadap penularan penyakit TB paru dengan cara makan-makanan bergizi, meningkatkan kesehatan lingkungan dan periksa dahak apabila batuk lebih dari 2 minggu. Penelitian selanjutnya perlunya dilakukan penelitian tentang faktor-faktor apa saja 
yang mempengaruhi terjadinya penyakit

TB paru di Kabupaten Indramayu.

\section{REFERENSI}

Azwar, A. (2001). Pengantar Epidemilogi. Jakarta. Binarupa Aksara

Erawatyningsih, E, Purwanta dan Subekti, H. (2009). Faktor-faktor yang Mempengaruhi Ketidakpatuhan Berobat Pada Penderita Tuberkulosis Paru. Journal Of Community Medicine and Publich Health (BKM). Volume 25 Nomor 3

Fitria, Eka. Raisuli Ramdhan dan Rosdiana.(2017). Karakteristik Penderita Tuberkolusis Paru di Puskesmas Rujukan Mikroskopis Kabupaten Aceh Besar. SEL Jurnal Penelitian Kesehatan, Volume 4 Nomor 1

Kemenkes, RI. (2010). Pedoman Penanggulangan Tubercolusis (TB). In: Kemenkes, editor. 2 ed. Jakarta.

Kemenkes, RI. 2015. Profil Kesebatan Indonesia. Jakarta

Laily, Dian Wahyu. Dina V, Rombot, Benedictus S. Lampus. (2015). Karakteristik Pasien Tuberkolusis Paru di Puskesmas Tuminiting Manado. Jurnal Kedokteran Komunitas dan Tropik, Volume 3 Nomor 1

Murti B. (1997). Prinsip dan Metode Riset Epidemiologi. Pertama, editor. Yogyakarta: Gadjah Mada University Press;

Notoatmodjo, S.(2007). Promosi kesehatan dan ilmu perilaku. Jakarta : Rineka Cipta
Panjaitan, Freddy. (2012). Karakteristik Penderita Tuberkolusis Paru Dewasa Rawat Inap di Rumah Sakit Dr. Soedarso Pontianak. Periode September-November 2010. Naskah Artikel, 2012

Prihantana,Anna Silvia. Sri Saptuti Wahyuningsih. (2016). Hubungan Antara Pengetahuan dengan Tingkat Kepatuhan Pengobatan pada Pasien Tuberkolusis di RSUD dr. Soehadi Prijonegiri Sragen. Jurnal Farmasi Sains dan Praktis, Volume II Nomor 1

Profil Kesehatan Propinsi Jawa Barat Tahun 2012

R. Beaglehole at all. (1997). Dasar-dasar epidemiologi, WHO, Geneva

Rukmini dan Chatarina UW. (2010). Faktor-faktor yang berpengarub Terbadap Kejadian TB Paru Dewasa di Indonesia (Analisis Data Riset Kesehatan Dasar Tabun 2010). Buletin Penelitian Sistem Kesehatan, Oktiber 2011, Volume 14 Nomor 4

Sihombing, H. Sembiring, H. Amir, Z dan Sinaga, B.Y.M. (2012). Pola Resistensi Primer Pada Penderita TB Paru Kategori I di RSUP H. Adam Malik, Medan. Journal Respir Indo. Volume 32 Nomor 3

Simbolon, D. (2007). Faktor Risiko Tuberculosis Paru di kabupaten Rejang Lebong. Volume 2 Nomor 3

Widoyono. (2011). Penyakit Tropis (Epidemiologi, Penularan, Pencegahan dan Pemberantasannya). 2, editor. Jakarta: Erlangga Medical Series.

WHO. (2011). Global Tuberculosis Control: WHO Global Report 2011 